\title{
Antisipasi Child Sexual Abuse Melalui Pengenalan Identitas Gender Anak Usia Dini Dengan Perspektif Pendidikan Islam
}

\author{
Nur Salamah $^{1}$, Ashif Az Zafi' ${ }^{2}$, Septia Nurul Wathani ${ }^{3}$ \\ ${ }^{1,2}$ Institut Agama Islam Negeri Kudus, Indonesia \\ ${ }^{3}$ Universitas Pendidikan Muhammadiyah Sorong, Indonesia \\ nursalamah6962@gmail.com
}

\begin{abstract}
Abstrak
Psikologi, fisik, sosial anak akan terganggu jika anak mengalami pelecehan seksual sejak dini. Upaya mencegah terjadinya kekerasan seksual terhadap anak usia dini dengan memberikan pendidikan seks kepada anak-anak usia dini melalui pengenalan identitas gender dalam perspektif pendidikan Islam. Dalam prosesnya, peneliti menggunakan pendekatan kualitatif. Data yang dihasilkan dikumpulkan melalui metode studi kepustakaan. Berdasarkan kepada penelitian yang dilakukan ditemukan adanya upaya antisipasi kekerasan seksual anak melalui menanamkan maskulinitas kepada anak laki-laki dan menanamkan jiwa feminitas kepada anak perempuan berdasarkan pengelompokan media dan jenis permainan, memisahkan tempat tidur, menanamkan budaya malu dan menutup aurat, mengenalkan waktu aurat, memahami bagaimana menjaga serta membersihkan alat kelamin, serta memahami perihal peristiwa baligh yang ditandai dengan khitan, ihtilam, dan haid yang disertai pembelajaran ilmu fiqih. Orang tua hingga lingkungan sekitar memiliki andil yang besar terkait dengan pendidikan seks untuk anak-anak. Melalui pengenalan identitas gender kepada anak usia dini diharapkan dapat menekan kasus kekerasan seksual anak serta mengubah perspektif masyarakat terhadap pendidikan seks bagi anak.

Kata Kunci: anak usia dini; identitas gender; kekerasan seksual
\end{abstract}

\section{Anticipation Of Child Sexual Abuse Through Recognition Of Gender Identity Of Early Children With Islamic Education Perspective}

\begin{abstract}
Psychological, physical, social children will be disturbed if the child is sexually abused from an early age. Efforts to prevent sexual violence against early childhood by providing sex education to early childhood through the introduction of gender identity in the perspective of Islamic education. In the process, the researcher used a qualitative approach. The resulting data were collected through the literature study method. Based on the research conducted, it was found that there were efforts to anticipate child sexual violence through instilling masculinity in boys and instilling a spirit of femininity in girls based on media grouping and types of games, separating beds, instilling a culture of shame and covering genitalia, introducing the time of genitalia, understanding how to maintain and clean the genitals, and understand the events of puberty marked by circumcision, ihtilam, and menstruation accompanied by the study of fiqh. Parents and the surrounding environment have a big role in sex education for children. Through the introduction of gender identity to early childhood, it is hoped that it can suppress cases of child sexual violence and change the community's perspective on sex education for children.
\end{abstract}

Keywords: children; gender identity; sexual abuse 


\section{PENDAHULUAN}

Kekerasan seksual atau sexual abuse bisa terjadi kepada siapapun (Anggraini \& Maulidya, 2020). Tidak hanya kepada orang dewasa maupun remaja, bahkan kekerasan seksual tidak hanya terjadi kepada kaum perempuan saja. Kenyataan di masyarakat menunjukkan fakta yang cukup mencengangkan, yakni tidak sedikit anak di bawah umur/anak usia dini menjadi korban dari kekerasan seksual. Kasus kekerasan seksual di Indonesia khususnya yang terjadi kepada anak usia dini memiliki jumlah yang cukup tinggi. Dilansir melalui laman resmi Kementrian Pemberdayaan Perempuan dan Perlindungan Anak Indonesia (Kemen PPPA), Asisten Deputi Bidang Perlindungan Anak dari Kekerasan dan Eksploitasi, Valentina Glintings menyampaikan bahwa selama pandemi per Juni 2020 telah terjadi sebanyak 3.087 kasus kekerasan kepada anak, dengan rinciannya 852 kasus kekerasan fisik, 768 kekerasan psikis, dan 1.848 kasus kekerasan seksual (Gintings, 2020).

Kekerasan seksual merupakan tindakan kejahatan yang cenderung menyerang organ genital seseorang dan dapat memberikan efek trauma baik secara fisik maupun psikis korban secara serius. Sehingga yang dimaksud dengan kekerasan seksual terhadap anak usia dini (child sexual abuse) adalah tindakan kejahatan seksual yang ditargetkan kepada anak usia dini. Bentuk-bentuk kekerasan seksual diantaranya dapat melalui kekerasan verbal seperti catcalling atau gurauan yang berbau seksualitas hingga perbuatan menyentuh atau lebih parahnya adalah pemerkosaan (Mardina, 2019). Oleh karena itu, tindak kekerasan seksual merupakan kejahatan yang keji dan wajib untuk diwaspadai. Anak merupakan aset berharga bangsa sebagai penerus roda perjuangan yang wajib untuk dilindungi masa depannya. Kekerasan seksual terhadap anak usia dini dapat terjadi karena beberapa faktor, diantaranya adalah karena kurangnya pengawasan orang tua kepada anak-anaknya dan perspektif masyarakat yang masih tabu terhadap pendidikan seks anak usia dini.

Terdapat sebuah penelitian yang juga menyebutkan bahwa salah satu faktor penyebab pelaku kejahatan melakukan tindak kekerasan seksual terhadap anak atau child sexual abuse adalah berawal dari dirinya sendiri yang merupakan korban dari child sexual abuse. Octaviana mengutip penelitian yang dilakukan oleh Rezmovic pada tahun 1996, dalam penelitian itu disebutkan bahwa sebanyak 23 dari 25 sampel pelaku kekerasan seksual terhadap anak mengatakan bahwa dirinya pernah menjadi korban kekerasan seksual anak semasa kecil mereka. Berdasarkan hal itu, tidak menutup kemungkinan akan adanya sebuah siklus berulang jika permasalahan terkait child sexual abuse tidak segera diatasi (Octaviana, 2019). Ketika 
anak usia dini mengalami kekerasan seksual atau pengalaman yang berbau pornografi untuk pertama kalinya, anak-anak akan cenderung merasa tidak nyaman dan merasa jijik sehingga menyebabkan aktifnya sistem limbik di otak anak. Ketika sistem limbik telah aktif maka ia akan memicu keaktifan sistem yang lain, yakni norepinefrin dan serotonin. Sistem tersebut akan memicu stimulus sistem limbik untuk meningkatkan perasaan nyaman, gembira, kepuasan hingga kecanduan. Jika anak usia dini menjadi korban kekerasan seksual secara berulang maka tidak menutup kemungkinan bahwa di kemudian hari korban akan menjadi pelaku kekerasan seksual itu sendiri (Anggraini \& Maulidya, 2020).

Beberapa kajian penelitian terdahulu yang relevan dengan kajian child sexual abuse diantaranya adalah kajian penelitian yang dilakukan oleh Wenjing Zhang, Ping Ren, Guijin Yin, \& Yichen Jin yang membahas menganai pencegahan kekerasan seksual berdasarkan pengetahuan orang tua, penelitian ini mengambil responden sebanyak 440 orang tua dengan hasil penelitian bahwa pendidikan seksual anak usia dini (preschool-aged) oleh masingmasing orang tua sangat diperlukan untuk mencegah terjadinya tindakan kekerasan seksual terhadap anak di China (Zhang et al., 2020). Selanjutnya berdasarkan kajian yang dilakukan oleh Olusimbo K. Ige dan Olufunmilayo I. Fawole meneliti tentang pencegahan kekerasan seksual terhadap anak di Nigeria berdasarkan persepsi orang tua dan praktiknya. Penelitian yang dilakukan oleh Olusimbo menyebutkan bahwa kekerasan seksual khususnya terhadap anak kecil merupakan permasalahan di masyarakat. Penelitian ini mengambil responden sebanyak 387 orang tua dan pengasuh anak dengan hasil penelitian sebanyak $27,1 \%$ orang tua meninggalkan anaknya tanpa pengawasan dan sebanyak lebih dari $90 \%$ orang tua sudah mendidik anaknya terkait dengan bahaya orang asing (Ige \& Fawole, 2011). Sedangkan kajian penelitian menurut Allinson N. Sinanan meneliti tentang impact atau dampak dari keluarga, pelayanan perlindungan anak, dan anak itu sendiri dalam mengurangi kekerasan seksual terhadap anak. Penelitian ini menunjukkan hasil bahwa kekerasan seksual terhadap anak dapat terjadi berulang kali terhadap korban. Oleh karena itu Allinson N. Sinnasan mengkaji bahwa tiga faktor penting yakni keluarga, layanan perlindungan anak, dan anak itu sendiri (Sinanan, 2011). Yang terakhir adalah kajian penelitian yang dilakukan oleh Tri Endang Jatmikowati, Ria Angin dan Ernawati menyebutkan bahwa maraknya kekerasan seksual terhadap anak usia dini khususnya di Indonesia menunjukkan betapa pentingnya memberikan pengajaran terkait pendidikan seks untuk anak usia dini. Dalam upaya memberikan pendidikan seks kepada anak usia dini Jatmikowati beserta rekan lainnya menggunakan perspektif gender. Diperoleh 
beberapa tema materi yang dapat diajarkan kepada anak usia dini yaitu: Aku dan Tubuhku, Aku dan Pakaianku, Keluarga dan Orang Sekitar, Cara Merawat dan Menjaga Tubuh (Jatmikowati et al., 2015).

Berdasarkan pada kajian penelitian terdahulu di atas terdapat relevansi dengan kajian penelitian yang akan dilakukan oleh peneliti, yakni mengkaji mengenai child sexual abuse atau kekerasan seksual terhadap anak dan upaya pencegahannya. Kemudian dijumpai persamaan lebih lanjut yaitu tentang pendidikan seks kepada anak usia dini dengan mengenalkan gender. Perbedaan secara umum antara kajian penelitian terdahulu dengan kajian penelitian yang akan dilakukan adalah penggunaan perspektif pendidikan Islam dalam upaya pencegahan atau antisipasi terjadinya child sexual abuse. Kajian penelitian terdahulu yang digunakan sebagai rujukan dipublikasikan di luar negeri yang mana Islam notabene sebagai agama minoritas sehingga tidak dijumpai nilai-nilai religiusitas.

Berdasarkan permasalahan yang ada berkaitan dengan kekerasan seksual terhadap anak maka penelitian ini memberikan sebuah alternatif untuk mengantisipasi terjadinya child sexual abuse melalui pendidikan seks berupa pengenalan identitas gender kepada anak usia dini dengan menggunakan perspektif pendidikan Islam. Penelitian ini bertujuan untuk mencegah terjadinya kekerasan seksual terhadap anak usia dini. Tujuan jangka panjang yang diharapkan adalah menyiapkan anak sejak dini untuk menghadapi persoalan hidup yang menyangkut gender menggunakan perspektif Islam. Manfaat dari penelitian ini adalah untuk mengetahui bagaimana proses pengenalan identitas gender dengan perpektif pendidikan Islam serta untuk mengubah sudut pandang masyarakat terhadap pentingnya pendidikan seks bagi anak usia dini dengan harapan kasus kekerasan seksual terhadap anak usia dini dapat berkurang bahkan hilang di kalangan masyarakat.

\section{METODE PENELITIAN}

Penelitian ini dikaji melalui pendekatan kualiatif dengan jenis penelitian yang digunakan adalah studi kepustakaan atau kajian literarur. Jenis penelitian studi kepustakaan memperoleh data dari mengadopsi teori-teori yang sudah ada di dalam referensi-referensi yang relevan dengan penelitian yang akan dilakukan sebagai rujukan dalam penelitian, yakni mengenai child sexual abuse (kekerasan seksual kepada anak) dan pengenalan identitas gender. Data yang diperoleh dalam penelitian ini diambil dari berbagai artikel google scholar yang terindeks SINTA maupun artikel internasional dari berbagai negara seperti China, 
Nigeria, dan Indonesia yang terindeks oleh SCOPUS. Analisis naratif yang digunakan dalam penelitian ini merupakan metode mengkaji sebuah narasi yang dapat meningkatkan pemahaman terkait dengan penelitian yang dilaksanakan (Kustanto, 2015).

\section{HASIL DAN PEMBAHASAN}

\section{A. Hasil}

Kekerasan seksual secara umum merupakan sebuah tindakan atau perbuatan yang menyerang organ genital korban baik dilakukan secara verbal maupun tindakan. Kekerasan seksual merupakan tindakan yang melanggar norma kesusilaan biasanya dilakukan dalam bentuk paksaan dan ancaman dari pelaku tindak kejahatan kepada korban kekerasan seksual (Mashudin, 2016). Menurut Undang-Undang nomor 35 tahun 2014 yang membahas tentang perlindungan anak, yaitu tercantum pada pasal 1 ayat 16 menyebutkan bahwa kekerasan terhadap anak merupakan setiap perbuatan yang berakibat munculnya perasaan sengsara atau perasaan menderita dari anak baik secara fisik, psikis, seksual dan/atau penelantaran yang dilakukan dengan ancaman, pemaksaan ataupun perampasan. Jadi, kekerasan seksual terhadap anak adalah seluruh tindakan atau perbuatan yang mengarah pada perilaku seksual kepada anak di bawah umur dengan cara kekerasan dan ancaman (Wiludjeng, 2016). Kekerasan seksual dapat memunculkan reaksi negatif dari korban kekerasan seperti perasaan malu, benci, marah, tersinggung, trauma, dan sebagainya. Bentuk-bentuk dari kekerasan seksual meliputi segala hal seksual yang dilakukan secara sepihak kepada korban, seperti: siulan nakal; main mata; komentar terkait bagian tubuh tertentu (body shaming); isyarat atau gerakan yang berkonotasi seksual; ajakan, iming-iming, atau ancaman untuk berkencan; ajakan berhubungan seksual hingga tindakan pemerkosaan (UNESCO Office Jakarta, 2013).

Kasus kekerasan seksual terhadap anak terjadi di Indonesia di setiap tahunnya. Pemerintah telah mencoba berupaya maksimal untuk melindungi hak anak khususnya agar mencegah terjadinya kekerasan terhadap anak melaui serangkaian peraturan perundangundangan. Undang-Undang yang dimaksud diantaranya adalah, Undang-Undang nomor 35 tahun 2014 tentang perlindungan anak. Perlindungan anak merupakan segala upaya yang dilakukan untuk menjamin dan melindungi hak-hak anak untuk hidup sesuai dengan harkat dan martabat manusia serta mendapatkan perlindungan dari tindakan kekerasan dan diskriminasi oleh siapapun. Apabila diketahui ada yang melanggar peraturan perundangundangan terkait perlindungan anak maka pelaku akan dikenai sanksi yang dicantumkan pada 
pasal 81 ayat 1 di dalam Undang-Undang Perlindungan Anak nomor 35 tahun 2019, yakni setiap orang yang melanggar ketentuan yang telah ditetapkan dijatuhi hukuman penjara paling singkat 5 tahun dan paling lama hingga 15 tahun beserta denda paling banyak sebesar Rp 5.000.000.000,00 (lima miliar rupiah). Dalam perspektif Islam tidak terdapat hukum yang secara spesifik membahas terkait sanksi terhadap perbuatan kekerasan seksual kepada anak usia dini. Sehingga, sanksi yang diberikan berupa jarimah ta'zir. Sanksi ta'zir merupakan hukuman yang bersifat mendidik agar jera atas tindak pidana yang hukumannya belum ada di hukum syara'. Kekerasan seksual dapat diklasifikasikan sebagai bentuk dari perbuatan zina. Sehingga pelaku kekerasan seksual berdasarkan hukum Islam dapat dijatuhi hukuman jilid sesuai jumlah yang diputuskan oleh hakim (Mashudin, 2016). Pada zaman Rasulullah pelaku zina benar-benar diberi hukuman yang berat dengan terlebih dahulu meninjau sasaran hukum. Hukum syariat Islam telah menetapkan empat bentuk hukuman untuk jarimah zina yaitu diantaranya (Abubakar et al., 2018):

a. Hukuman jilid

Berupa hukuman cambuk atau dera kepada pelaku zina yakni sebanyak seratus kali cambukan. Dalam Q.S. An-Nur ayat 2 dijelaskan bahwa hukuman jilid ini selayaknya dipertontonkan di hadapan orang banyak. Praktik hukuman cambuk atau dera masih berlaku di Aceh yang menggunakan hukum syariat Islam. Hukuman dera dijatuhkan kepada pelaku dengan kategoi ghairu muhsan. Artinya, pelaku berstatus belum menikah.

b. Hukuman Pengasingan

Berupa tindakan mengeluarkan atau mengusir pelaku perbuatan zina dari tempat tinggalnya untuk ke tempat lain.

c. Hukuman rajam

Berupa hukuman mati dengan cara melempari para pelaku perbuatan zina dengan batu ataupun sejenisnya. Hukuman ini ditujukan kepada pelaku zina yang muhsan atau sudah menikah namu tetap berbuat zina.

d. Hukuman harta, yakni berupa hukuman yang diberikan kepada harta benda seperti denda, perampasan, dan diyat.

Kekerasan seksual baik secara umum maupun kekerasan seksual terhadap anak usia dini memiliki dampak terhadap beberapa aspek, diantaranya adalah dampak pada aspek psikologis, dampak fisik, dan dampak sosial. Bentuk dari dampak psikologis biasanya korban 
cenderung merasa kehilangan harga diri sehingga timbul hilang kepercayaan kepada diri sendiri, depresi, ketakutan, kecemasan, dan mudah marah. Dampak fisik yang dirasakan korban diantaranya adalah sakit kepala, gangguan terhadap pola makan, perasaan mual, dan berat badan menurun drastis. Dampak sosial dari kekerasan seksual diantaranya adalah kehilangan semangat untuk bersosialisasi, merusak hubungan sosial, dan menurunnya produktivitas individu (UNESCO Office Jakarta, 2013). Terlebih lagi jika korban dari kekerasan seksual adalah anak usia dini, dampak yang ditimbulkan diantaranya adalah merusak moral anak, memberikan trauma yang mendalam, dan berkemungkinan sekali untuk menghancurkan masa depan anak.

Pengertian anak usia dini berdasarkan dengan apa yang tercatat di dalam UndangUndang nomor 20 tahun 2003 tentang Sistem Pendidikan Nasional (UU Sisdiknas) adalah anak dengan rentang usia 0 tahun sampai 6 tahun. Disampaikan pula di dalam UU Sisdiknas mengenai pengertian pendidikan anak usia dini, yaitu setiap daya dan upaya sadar terkait pembinaan dan pemberian bimbingan terhadap anak sejak lahir hingga berusia 6 tahun yang diselenggarakan melalui dorongan stimulus nilai-nilai dalam pendidikan guna membantu pertumbuhan dan perkembangan jasmani serta rohani anak usia dini agar siap dalam mengikuti jenjang pendidikan selanjutnya. Masa anak-anak dalam rentang usia 0-6 tahun atau sebagian ahli menyebutkan 0-8 tahun disebut dengan the golden age atau periode keemasan. Segala sesuatu yang dialami anak dalam periode keemasan memiliki potensi besar untuk mempengaruhi masa depan anak. Begitu pula dengan pengalaman-pengalaman yang dialami dalam periode keemasan cenderung bertahan lama bahkan bisa saja tidak dapat dilupakan (Sunanih, 2017).

Perkembangan yang terjadi pada anak usia dini meliputi perkembangan pada aspek fisik, kognitif, motorik, bahasa, emosi, dan sosial. Lingkungan sekitar baik keluarga, masyarakat, lingkungan pendidikan serta bagaimana pola asuh anak sangat memperngaruhi perkembangan anak (Kementerian Pemberdayaan Perempuan dan Perlindungan Anak, 2020). Saat-saat periode keemasan otak anak merekam dengan baik apa yang di representasikan oleh lingkungan sekitarnya. Oleh karena itu, baik orang tua, saudara, dan masyarakat sekitar hendaknya menyiapkan diri agar menjadi suri tauladan yang baik bagi anak-anak.

Pada rentang anak usia dini yakni sekitar 0-8 tahun, aspek kognitif sedang mengalami perkembangan yang begitu pesatnya. Hal itu menyebabkan anak dapat mempelajari segala sesuatu dengan mudah jika mendapatkan pola pengasuhan yang tepat. Secara umum, 
perkembangan anak usia dini mencakup perkembangan motorik, perkembangan kognitif, perkembangan bahasa, dan perkembangan sosial (Kementerian Pemberdayaan Perempuan dan Perlindungan Anak, 2020). Dengan adanya Pendidikan Anak Usia Dini, aspek-aspek yang meliputi perkembangan anak dapat meningkat. Sehingga dengan otomatis prestasi dan kepribadian anak juga akan turut serta meningkat. Seperti halnya ketika anak usia dini mengalami pengalaman yang tidak menyenangkan, maka hal itu akan berdampak besar bagi kehidupan selanjutnya. Salah satu pendidikan yang teramat penting bagi anak usia dini adalah pendidikan seks.

Pendidikan seks terhadap anak usia dini adalah sebuah upaya yang dilakukan untuk meningkatkan awareness atau kesadaran baik kepada orang tua, masyarakat, dan yang terpenting anak tentang masalah seksual yang dihadapi oleh anak agar terhindar dari segala perbuatan yang dilarang oleh norma maupun agama. Pendidikan seks juga merupakan sebuah upaya untuk memberikan pengetahuan tentang pengenalan anatomi tubuh manusia khususnya pada organ genital atau organ reproduksi terkait perubahan-perubahannya serta fungsinya dengan menanamkan nilai-nilai etika, moral, agama, sehingga tidak terjadi penyalahgunaan terhadap organ genital tersebut (Dewi \& Bakhtiar, 2020). Dalam sudut pandang agama Islam, pendidikan seks adalah upaya bimbingan dan pengajaran serta pengarahan terkait sebuah perintah, anjuran, hingga larangan yang bersumber dari dalil-dalil agama. Dalam ranah pendidikan seks yang dimaksud seperti, menjaga kemaluan, menundukkan pandangan, dan menjauhi perbuatan zina (Oktarina \& Suryadilaga, 2020). Seperti yang difirmankan Allah melalui Q.S. Al-Isra' ayat 32 mengenai larangan berzina:

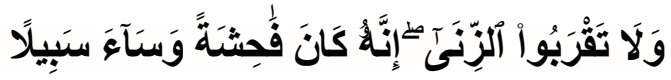

Artinya:"Dan janganlah kamu mendekati zina, sesungguhnya zina itu adalah suatu perbuatan yang keji dan suatu jalan yang buruk."

Tujuan pendidikan seks bervariasi, sesuai dengan rentang waktu usia manusia. Secara umum bagi anak usia dini pendidikan seks bertujuan untuk sebagai berikut:

1. Membantu anak mengetahui perkara-perkara pertumbuhan biologis meliputi perubahan fisik, masa puber, hingga kehamilan.

2. Melindungi anak dari tindak kekerasan seksual

3. Mencegah anak dari munculnya kelainan seksual

4. Mencegah kasus hubungan seksual bagi remaja di bawah umur

5. Mengurangi kasus penularan penyakit lewat seks seperti HIV AIDS 
6. Mengenalkan peran laki-laki dan perempuan (Dewi \& Bakhtiar, 2020)

Berdasarkan tujuan di atas secara garis besar dapat disimpulkan bahwa tujuan pendidikan seks khususnya dalam perspektif Islam, tujuan dari pendidikan seks bagi anak usia dini diantaranya adalah:

1. Mengenalkan anak usia dini kepada perbedaan antara alat kelamin laki-laki dan perempuan

2. Memberi tahu perihal keluarga tentang mahram dan non-mahram, memberi tahu asalusul keluarga

3. Menjaga kebersihan alat kelamin melalui thoharoh (bersuci)

4. Menghindarkan anak dari perbuatan keji yaitu berzina

Tujuan penting selanjutnya dari diselenggarakannya pendidikan seks bagi anak usia dini adalah untuk mengubah pola pikir serta memberikan kesadaran kepada masyarakat luas termasuk orang tua, kerabat keluarga, dan pendidik terkait pentingnya pendidikan seks kepada anak usia dini guna menjaga anak-anak dari hal-hal yang tidak diinginkan, salah satunya adalah kekerasan seksual.

Pola pikir masyarakat yang masih tabu terhadap pendidikan seks bagi anak usia dini harus dihilangkan. Mayoritas masyarakat masih berpikir bahwa ranah pendidikan seks hanya berkisar tentang hubungan seksual. Lebih jauh dari itu, bahwa pengenalan terhadap identitas gender juga termasuk ke dalam ranah pendidikan seks. Pendidikan seks bagi anak usia dini difokuskan agar anak-anak memahami bagaimana kondisi tubuh mereka sendiri, pemahaman tentang perbedaan jenis kelamin (lawan jenis) dan yang terakhir adalah untuk menghindarkan anak usia dini dari tindak kekerasan seksual. Inilah poin-poin penting pendidikan seks bagi anak usia dini, yang kemudian diharapkan dapat menurunkan tindak kekerasan seksual yang terjadi kepada anak usia dini. Tahapan-tahapan dalam pendidikan seks kepada anak usia dini dimulai dengan mengenalkan nama-nama anatomi tubuh anak termasuk alat kelamin anak. Para orang tua cenderung merubah atau mengganti istilah alat kelamin anak daripada menyebutkan nama asli dari alat kelamin tersebut. Orang tua harus berani mengenalkan 'vagina' sebagai alat kelamin perempuan kemudian 'penis' sebagai alat kelamin laki-laki. Tahap selanjutnya adalah dengan 'toilet training'. Toilet training merupakan upaya melatih anak untuk buang air kecil (BAK) dan buang air besar (BAB) pada tempatnya. Toilet Training mengajarkan kepada anak bahwa ada anggota badan yang tidak boleh dilihat dan disentuh oleh orang lain. Kemudian melaului toilet training orang tua dapat secara sekaligus 
mengajarkan anak bagaimana cara membersihkan anggota badannya sendiri sehingga tidak membutuhkan bantuan orang lain. Pengembangan materi terkait pendidikan seks harus disesuaikan dengan aspek kognitif, aspek afektif, dan aspek psikomotorik anak sehingga dalam penyampaian materi pendidikan seks kepada anak harus dilakukan dengan penuh perhatian dan tidak terlalu vulgar. Perihal gender harus mulai dikenalkan kepada anak sejak usia dini. Pengenalan gender kepada anak usia dini dapat didasarkan kepada tiga hal, yaitu identitas gender, stereotip peran gender, dan pola perilaku gender (Jatmikowati et al., 2015).

Identitas gender (gender identity) harus dipahami anak sebagai atribut yang tidak dapat dirubah. Proses pemahaman dimulai ketika anak berusia 6 bulan bisa membedakan figur seorang ibu dan figur seorang ayah melalui suaranya. Memasuki rentang usia 2-3 tahun, anak mampu membedakan identitas gender dengan penyebutan keduanya dengan tepat sesuai label ayah/bapak/papah/abi dan bunda/ibu/mamah/ummi. Ketika memasuki usia sedikit lebih besar yakni 5-7 tahun anak akan secara naluri memahami bahwa identitas gender tidak bisa diubah.

Stereotip peran gender (gender role stereotype) merupakan proses pemahaman tentang peran yang dijalankan oleh masing-masing laki-laki dan masing-masing perempuan. Proses pemahaman terkait stereotip peran gender dimulai ketika anak memasuki usia 2,5-3 tahun. Proses pengenalan terhadap peran gender ini dapat dilakukan dengan penggunaan metode dan media dalam bermain bagi anak laki-laki dan perempuan. Anak laki-laki cenderung menyukai permainan outdoor, permainan yang membutuhkan banyak tenaga seperti permainan olahraga dan mobil-mobilan. Hal ini menggiring anak laki-laki untuk paham perannya di kemudian hari adalah untuk bekerja mencari nafkah serta untuk melindungi keluarganya. Sedangkan anak perempuan cenderung dibimbing dalam permainan indoor seperti bermain boneka, masak-masak, dan permainan belanja. Hal ini bertujuan untuk mengenalkan peran utama perempuan adalah untu mengurus anak dan mengelola rumah tangga.

Perilaku gender merupakan kecenderungan anak terhadap hal-hal yang disukainya, seperti kegiatan yang secara normal merupakan representasi dari jenis kelamin laki-laki atau perempuan.hal ini dapat diobservasi melalui objek permainan yang digunakan anak-anak, teman sebaya sepermainan, aktivitas yang disukai anak, dan bagaimana cara berpakaian anak. Bahkan ketika anak baru menginjak usia 1,5-2 tahun perilaku gender sudah dapat diketahui melalui anak laki-laki yang lebih cenderung menyukai mbobil-mobilan dan anak perempuan yang cenderung menyukai boneka (Jatmikowati et al., 2015). 
Sebuah organisasi yang bergerak dalam kegiatan kemanusiaan di Eropa, yaitu The Council of Europe menciptakan sebuah konsep yang disebut Underwear Rule. Underwear Rule merupakan sebuah pedoman sederhana agar memudahkan orang tua dalam menjelaskan kepada anak-anaknya tentang bahaya orang lain (baik orang yang dikenal maupun orang yang tidak dikenal) yang tidak diperbolehkan untuk menyentuh tubuh anak yang tertutup oleh pakaian dalam. Adapun konsep Underwear Rule yang digunakan adalah PANTS, yang memiliki makna:

$\mathrm{P}$ (Privates are private)

Artinya, anggota tubuh anak yang tertutup oleh pakaian dalam adalah privasi. Tidak ada yang boleh melihatnya apalagi menyentuhnya. Kecuali dokter dan suster untuk kepentingan pemeriksaan.

\section{A (Always Remember Your Body Belongings To You)}

Artinya "Tubuhmu adalah milikmu". Melalui ini orang tua mengajarkan kepada anak untuk menghargai tubuh yang dimilki dengan tidak membiarkan orang lain melakukan sesuatu yang menimbulkan rasa malu, marah, dan tidak nyaman.

\section{N (No Means No)}

Anak berhak untuk berkata "tidak", jika ada yang membuatnya merasa tidak nyaman.

\section{T (Talk Abaout Secrets That Upset You)}

Artinya, "Berbicaralah tentang rahasia yang membuatmu merasa kesal", Orang tua mengajarkan anak untuk tidak menyimpan rahasia apalagi rahasia tersebut membuat anak merasa kesal dan tidak nyaman.

\section{S (Speak Up, Someone Can Help)}

Orang tua harus mengajarkan anak bersikap jujur dan meminta tolong terutama perihal yang menyangkut fisik, perasaan, dan pikiran yang membuat anak khawatir atau merasa kesal. Orang tua sudah seharusnya membangun kepercayaan anak kepada diri mereka dengan baik. Sehingga jika ada sesuatu yang terjadi kepada anak, anak akan leluasa bercerita kepada orang tua (Wiludjeng, 2016).

Penyimpangan-penyimpangan perilaku seksual dewasa ini kian merebak di masyarakat. Manusia berbondong-bondong untuk menuruti hawa nafsunya didukung dengan keadaan sosial yang semakin tercemar oleh budaya yang terlampau bebas. Pembinaan pribadi terhadap masing-masing anggota keluarga merupakan hal yang mutlak. Keluarga adalah unit terkecil dalam ruang lingkup masyarakat. Kewajiban bagi orang tua untuk mendidik dan 
mengarahkan anak-anaknya agar tidak terjerumus atau tidak menjadi korban kerusakan zaman. Begitupun terkait masalah seksualitas. Orang tua wajib untuk membekali anakanaknya pendidikan seksual yang sesuai dengan tuntunan ajaran agama Islam. Terlepas dari persepsi masyarakat yang masih menganggap pendidikan seks bagi anak merupakan hal tabu, jijik, dan kotor, Islam telah memberikan pedoman-pedoman yang bersifat praktis (Anggraini \& Maulidya, 2020). Islam sebagai agama yang universal mengatur seluruh urusan manusia. Pendidikan seksual merupakan bagian dari pendidikan akhlak. Kemuliaan akhlak tidak dapat diraih tanpa keimanan yang kokoh dan lurus (Fitri \& Na'imah, 2020). Oleh karena itu, dalam upaya memberikan pendidikan seks kepada anak haruslah berdasar kepada nilai-nilai keimanan. Mengutip pemikiran dari Muhammad Taqi al-Falsafi, menyebutkan bahwa orang tua harus menanamkan nilai-nilai keimanan sejak anak berusia dini. Penanaman nilai-nilai keimanan sejan anak berusia dini akan menumbuhkan kecerdasan dan kedermawanan bagi anak. Muhammad Taqi al-Falsafi mengibaratkan ruh seorang anak sebagai tanah yang subur. Jadi orang tua harus menanam benih kebajikan kepada mereka (Fariq et al., 2021).

Masyarakat menganggap bahwa pendidikan seks untuk anak usia dini merupakan hal yang tabu. Masih banyak orang tua yang masih kebingungan bagaimana cara memulai pendidikan seks bagi anak-anaknya. Ada rasa malu yang sudah melekat karena kultur masyarakat yang masih asing terhadap pendidikan seks bagi anak. Menjaga keamanan anak merupakan amanat yang diberikan oleh Tuhan kepada masing-masing orang tua. Sangat disayangkan, dewasa ini kejahatan seksual banyak meraja lela di kalangan masyarakat. Sehingga tugas orang tua untuk menjaga anak harus lebih ditingkatkan.

Pokok-pokok pendidikan seksual yang perlu diterapkan kepada seorang anak diawali dengan pengenalan identitas gender, yakni dengan menanamkan jiwa maskulinitas kepada anak laki-laki dan menanamkan jiwa feminitas kepada anak perempuan. Selanjutnya yakni mengenalkan anak-anak kepada siapa mahrom-nya dan siapa yang bukan mahrom, memisahkan tempat tidur anak laki-laki dan anak perempuan, mendidik anak berpakaian sesuai dengan tuntutan agama Islam yaitu menutup aurat. Berikut ini adalah penjelasan lebih lanjut terkait pendidikan seks anak usia dini melalui pengenalan identitas gender dengan menggunakan perspektif Islam. 


\section{B. Pembahasan}

1. Menanamkan jiwa maskulinitas pada anak laki-laki dan jiwa feminitas pada anak perempuan

Allah menciptakan manusia dengan fitrahnya masing-masing. Seperti halnya mengenai tampilan fisik, psikis, kognitif, afektif, dan psikomotorik antara laki-laki dan perempuan. Secara tampilan fisik, anak laki-laki jelas berbeda dengan anak perempuan. Sejak awal, anak harus dikenalkan dengan nama-nama anggota tubuh termasuk alat kelamin dengan nama yang benar. Dari segi kekuatan, anak laki-laki dikaruniai fisik yang lebih kuat dibandingkan dengan fisik anak perempuan. Kemudian ditinjau dari aspek psikis dan afektif anak perempuan cenderung lebih lembut dan lebih penuh kasih dibandingkan dengan psikis dan aspek afektif anak lakilaki. Semua fitrah ini mengarah kepada kewajiban-kewajiban yang akan ditanggung oleh masing-masing anak di masa depannya nanti. Yakni, figur seorang laki-laki haruslah kuat karena memiliki kewajiban untuk mencari nafkah dan melindungi keluarga. Sedangkan perempuan dianugerahi rahim untuk mengasihi dan menyayangi orang-orang disekitarnya. Bentuk ikhtiar untuk menanamkan jiwa maskulinitas kepada anak laki-laki dan menanamkan jiwa feminitas kepada anak perempuan adalah dengan mengarahkan kegiatan sehari-hari anak seperti bermain dengan menggunakan metode dan media sesuai identitas gender atau jenis kelamin anak. Terlepas dari realita kesetaraan gender di tengah masyarakat modern. Tidak menutup kemungkinan bagi seorang anak laki-laki untuk bekerja sebagai seorang chef ataupun seorang anak perempuan yang bekerja sebagai seorang arsitek. Pengelompokan terhadap metode dan jenis media berdasarkan jenis kelamin anak bertujuan untuk menguatkan fitrah berdasarkan jenis kelamin anak.

2. Memisahkan tempat tidur

Pemisahan tempat tidur bagi anak dengan orang tua dapat dilakukan ketika anak sudah memasuki usia 2 atau 3 tahun. Tujuan pemisahan tempat tidur ini agar anak terhindar mentehaui kegiatan orang tua salah satunya adalah kegiatan seksual sebelum pada waktunya (Mukti, 2016). Selanjutnya pemisahan tempat tidur antara anak laki-laki dan anak perempuan dapat dilakukan ketika anak berusia 7-10 tahun. Rasulullah bersabda, 
عن عمرو بن شعيب، عن أبيه، عن جده ـرضي الله عنهـ قال: قال رسول الله _صلى الله عليه وسلم-:

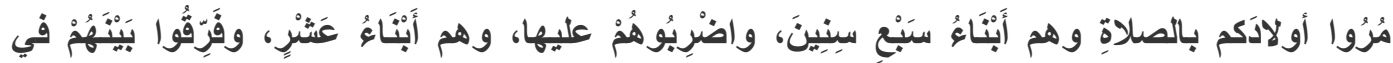

"Suruhlah anak-anakmu untuk sholat ketika berumur tujuh tahun, dan pukullah mereka (jika tidak mau sholat) ketika berumur sepuluh tahun, dan pisahkanlah tempat tidur mereka." (H.R. Abu Dawud)

Pemisahan tempat tidur antara anak laki-laki dengan anak perempuan merupakan sebuah upaya menghindarkan bahaya yang mungkin terjadi jika anak lakilaki dan anak perempuan dibiasakan tidur bersama dalam satu kasur ataupun dalam satu selimut sebab terjadinya sentuhan. Pemisahan ini juga bertujuan untuk menghindari terjadinya kelainan seksual incest atau hubungan intim antara saudara laki-laki dengan saudara perempuan. Dalam Q.S. An-Nisa ayat 23 Allah berfirman:

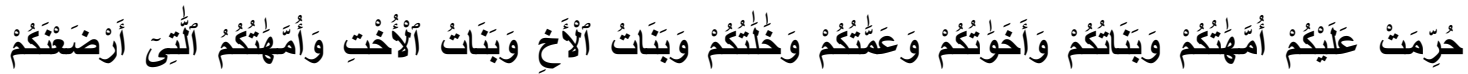

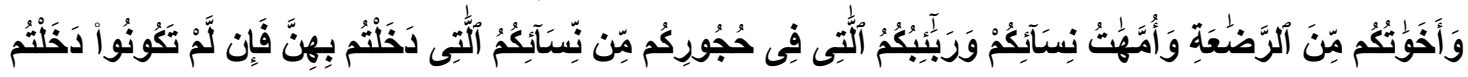

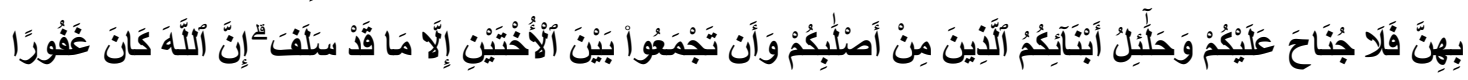

Artinya: "Diharamkan atas kamu (mengawini) ibu-ibumu; anak-anakmu yang perempuan; saudara-saudaramu yang perempuan, saudara-saudara bapakmu yang perempuan; saudara-saudara ibumu yang perempuan; anak-anak perempuan dari saudara-saudaramu yang laki-laki; anak-anak perempuan dari saudara-saudaramu yang perempuan; ibu-ibumu yang menyusui kamu; saudara perempuan sepersusuan; ibu-ibu isterimu (mertua); anak-anak isterimu yang dalam pemeliharaanmu dari isteri yang telah kaтu campuri, tetapi jika kamu belum campur dengan isterimu itu (dan sudah kamu ceraikan), maka tidak berdosa kamu mengawininya; (dan diharamkan bagimu) isteri-isteri anak kandungmu (menantu); dan menghimpunkan (dalam perkawinan) dua perempuan yang bersaudara, kecuali yang telah terjadi pada masa lampau; sesungguhnya Allah Maha Pengampun lagi Maha Penyayang."

3. Menanamkan Rasa Malu dan Menutup Aurat

Sejak awal, orang tua harus mengajarkan kepada anak bahwa tubuh anak adalah sebuah amanah yang harus dijaga dan dilindungi oleh anak sendiri, selain oleh kedua orang tua. Orang tua harus mulai menanamkan rasa malu kepada anak sejak usia dini khususnya terkait dengan anggota tubuhnya. Ajarkan kepada anak untuk 
berpakaian tertutup sesuai dengan ajaran agama dan biasakan anak untuk tidak suka bertelanjang sejak dini. Proses membentuk karakter malu dalam ranah positif kepada anak memang harus dilakukan secara bertahap. Hal ini ditinjau dengan kewajiban menutup aurat belum berlaku bagi anak usia dini. Tahap pertama adalah mengenalkan pengertian aurat kepada anak. Di dalam ajaran Islam, aurat adalah batas-batas tubuh manusia yang tidak boleh diperlihatkan. Tahap selanjutnya adalah memberi pengertian kepada anak bagian tubuh mana saja yang harus ditutup dan bagian mana saja yang boleh terbuka (Habibie, 2017). Terkhusus untuk anak perempuan, maka orang tua hendaknya mengenalkan kepada penggunaan kerudung sejak dini dengan cara memberikan contoh berpakaian yang sesuai dengan tuntunan Islam. Peran seorang ibu dalam proses ini sangat dibutuhkan. Orang tua harus sabar dan telaten demi kebaikan anak di kemudian hari. Seiring dengan menumbuhkan rasa malu dan mengenalkan anak untuk menutup aurat, orang tua juga harus mengenalkan kepada anak siapa mahrom dan siapa yang bukan mahrom. Hal ini bertujuan agar anak mulai terbiasa untuk disiplin dalam menjaga aurat dengan tidak sembarangan membuka aurat di dalam lingkup keluarga. Salah satu dasar dari perintah untuk menutup aurat terdapat pada Q.S. Al-Ahzab ayat 59:

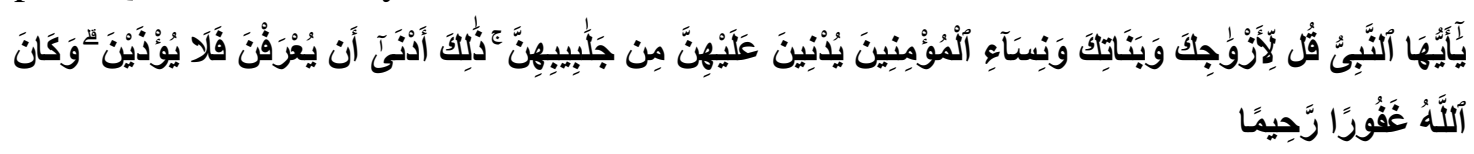

Artinya: "Hai Nabi, katakanlah kepada isteri-isterimu, anak-anak perempuanmu dan isteri-isteri orang mukmin: "Hendaklah mereka mengulurkan jilbabnya ke seluruh tubuh mereka". Yang demikian itu supaya mereka lebih mudah untuk dikenal, karena itu mereka tidak di ganggu. Dan Allah adalah Maha Pengampun lagi Maha Penyayang."

4. Mengenalkan Waktu Berkunjung

Dalam Islam terdapat waktu aurat, yakni dimana pada waktu tersebut aurat manusia cenderung terbuka. Waktu aurat meliputi waktu-waktu seperti sebelum sholat subuh, memasuki tengah hari, dan selepas sholat isya'. Dalam waktu tersebut anakanak diminta untuk izin sebelum memasuki ruangan atau kamar orang tuanya maupun saudara-saudaranya untuk menghindarkan anak melihat aurat yang mungkin tersingkap. Sikap meminta izin kepada orang tua, atau sikap meminta izin secara 
umum harus ditanamkan kepada anak sehingga lahirlah kepribadian anak yang luhur, menghormati privasi orang lain, dan taat sesuai dengan ajaran agama Islam.

5. Mengajarkan Untuk Menjaga Kebersihan Alat Kelamin

Islam mengajarkan untuk menjaga kebersihan, karena Allah sendiri menyukai kebersihan dan keindahan. Sejak usia dini, anak-anak sudah sepantasnya belajar mengenai membersihkan bagian tubuhnya sendiri terutama bagian-bagian tubuh intim yang meliputi bawah leher hingga lutut. Membersihkan diri atau bisa disebut dengan thoharoh selain sebagai ajaran agama Islam juga bermanfaat untuk menghindarkan anak dari kekerasan seksual. Salah satu bentuk pendidikan anak usia dini adalah toilet training. Melalui toilet training anak-anak akan terbiasa mandiri untuk membersihkan anggota tubuhnya tanpa bantuan orang lain.

6. Khitan dan Ihtilam

Khitan memiliki makna memotong bagian depan. Khitan yaitu memotong kulit bagian depan dari alat kelamin laki-laki atau tutup kepala zakar (kulup). Khitan merupakan salah satu syariat agar menjaga kebersihan tubuh dan memiliki manfaat dalam segi medis. Ihtilam adalah peristiwa fisiologis bagi manusia khususnya laki-laki ketika memasuki usia baligh. Ihtilam terjadi sebagai sebuah peristiwa berupa mimpi yang disertai keluarnya sperma (ejakulasi). Ketika seorang anak laki-laki telah mengalami ihtilam maka ia berkewajiban untuk menjalankan segala kewajiban dalam beragama. Jika tidak menjalankan kewajiban tersebut maka terhitung telah berbuat dosa. Ihtilam juga sebagai penanda bahwa organ reproduksi anak laki-laki telah mencapai kematangan. Pendidikan mengenai khitan dan ihtilam sudah sepantasnya diajarkan kepada anak laki-laki agar ketika peristiwa itu terjadi kepada mereka, mereka dapat menyikapi dengan tenang dan dapat terhindar dari perbuatan yang tercela. Seiring dengan peristiwa baligh nyaseorang laki-laki, baik orang tua ataupun guru di sekolah hendaknya mengajarkan fiqih thoharoh atau bersuci. Peristiwa ihtilam atau mimpi basah menyebabkan seorang laki-laki dalam keadaan junub yang mana dalam keadaan junub tersebut tidak sah jika mendirikan sholat, sehingga harus mandi junub terlebih dahulu untuk kembali dalam keadaan suci untuk mendirikan sholat atau ibadah lainnya. Oleh karena itu dibutuhkan pembelajaran fiqih kepada anak-anak. 
7. Haid

Haid merupakan peristiwa dimana darah keluar dari vagina akibat tidak terbuahinya sel telur (ovum) sehingga mengakibatkan dinding rahim yang disediakan untuk menguatkan bayi luruh. Haid merupakan tanda matangnya organ biologis anak perempuan yang mulai terjadi dalam rentang usia 12-14 tahun. Dalam kondisi tertentu menarche atau haid pertama bisa terjadi sebelum atau sesudah rentang usia pada umumnya. Untuk menghadapi menarche, yang perlu disiapkan adalah pemahaman dan mental anak perempuan (Hidayah \& Palila, 2018). Dilansir melalui laman Kids Health, kapan waktu yang baik untuk membicarakan tentang haid kepada anak-anak adalah usia 6-7 tahun. Orang tua harus pandai mencari waktu yang tepat untuk membicarakan mengenai haid. Beberapa momen yang tepat untuk mengenalkan anak tentang haid ataupun pubertas secara umum adalah sebagai berikut:

a. Anak-anak bertanya mengenai perubahan tubuhnya

b. Anak-anak bertanya dari mana bayi berasal

Jika anak-anak tidak bertanya mengenai hal-hal tersebut, orang tua terutama Ibu hendaknya melakukan inisiatif seperti mengajak anak ketika membeli pembalut kemudian menjelaskan kegunaan dari pembalut yang dibeli (Miller, 2018).

Persiapan selanjutnya adalah memahamkan anak-anak tentang hukum Islam terhadap haid. Setelah memahami apa itu haid maka selanjutnya adalah mengenalkan perkaraperkara yang dilarang bagi perempuan yang sedang haid, diantaranya adalah:

a. Tidak diperbolehkan untuk mendirikan sholat

b. Tidak diperbolehkan untuk menjalankan ibadah puasa selama bulan ramadhan

c. Tidak boleh beribadah thawaf

Karena haid merupakan tanda baligh-nya seorang perempuan, maka orang tua maupun orang-orang disekitar anak harus selalu mengingatkan kewajiban sebagai seorang muslim, seperti sholat, puasa, dan menjaga kehormatan. Seiring dengan hal itu, anak-anak sebaiknya dibekali pembelajaran fiqih guna mengetahui seluk beluk haid. Haid adalah sebuah hadas yang menyebabkan tidak diterimanya ibadah seperti sholat. Ilmu fiqih diperlukan untuk mengupas haid dan bagaimana cara bersuci dari haid sebelum melakukan ibadah kembali. 


\section{SIMPULAN DAN SARAN}

Child sexual abuse dapat dihindari jika anak-anak senantiasa dalam pantauan orang tua, masyarakat sekitar yang kondusif dan memberikan anak-anak pendidikan seks. Pendidikan seks terhadap anak usia dini bukanlah hal yang tabu. Pendidikan seks bagi anak usia dini justru merupakan bekal yang teramat berharga bagi anak dalam menjalankan kehidupannya di masa mendatang. Tujuan dari pendidikan seks adalah agar anak-anak memahami bagaimana kondisi tubuh dan fungsi-fungsinya serta sebab akibat atas setiap perbuatannya. Pendidikan seks akan lebih terstruktur melalui perspektif identitas gender, sehingga orang tua maupun masyarakat dapat secara tepat memilih metode dan media yang tepat selama proses pendidikan seksual. Dasar-dasar pengenalan identitas gender dalam perspektif Islam diantaranya adalah mengenalkan fitrah anak berdasarkan jenis kelamin melalui pengelompokan jenis dan media permainan, menanamkan rasa malu melalui pengenalan aurat dan syariat menutup aurat, mengenalkan mahrom dan non mahrom, mengajarkan tentang khitan dan haid yang disertai dengan pembelajaran fiqih.

Pendidikan seks dapat mencegah terjadinya child sexual abuse atau kekerasan seksual yang menargetkan anak-anak. Melalui pendidikan seks dengan melalui pengenalan identitas gender, anak-anak akan terbiasa untuk menjaga privasi, mengetahui adab bergaul dengan lawan jenis, berhati-hati dengan orang lain (baik orang terdekat maupun orang asing, lawan jenis maupun berjenis kelamin sama), saling terbuka kepada orang tua dan orang yang dipercaya, dan membentuk sikap yang religius bagi anak-anak. Beberapa hal tersebut merupakan hal-hal dasar yang dapat menghindarkan anak dari child sexual abuse atau kekerasan seksual terhadap anak.

\section{DAFTAR PUSTAKA}

Abubakar, A., Munir, B., \& Harahap, C. S. (2018). Anksi Bagi Pelaku Zina (Perbandingan Qanun No. 6 Tahun 2014 Dan Enakmen Jenayah Syariah Negeri Selangor No. 9 Tahun 1995 Seksyen 25). PETITA: Jurnal Kajian Ilmu Hukum Dan Syariah, 3(2), 176-200. https://doi.org/https://doi.org/10.22373/petita.v3i2.54 SANKSI

Anggraini, T., \& Maulidya, E. N. (2020). Dampak Paparan Pornografi Pada Anak Usia Dini. Al-Athfaal: Jurnal Ilmiah Pendidikan Anak Usia Dini, 3(1), 45-55. https://doi.org/10.24042/ajipaud.v3i1.6546

Dewi, R., \& Bakhtiar, N. (2020). Urgensi Pendidikan Seksual Dalam Pembelajaran Bagi Siswa Mi/Sd Untuk Mengatasi Penyimpangan Seksual. Instructional Development 
Journal, 3(2), 128. https://doi.org/10.24014/idj.v3i2.11697

Fariq, W. M., Darwis, M., Sofiani, I. K., \& Umar, A. N. (2021). Peran Orang T Ua Dalam Mendidik Anak Perspektif Muhammad Taq̄i Al - Falsafī ; Tela'ah Kitab Al-Thifl Baina Al-Waratsah Wa Al-Tarbiyah. Al-Athfaal: Jurnal Ilmiah Pendidikan Anak Usia Dini, 4(1), 106-123.

Fitri, M., \& Na'imah, N. (2020). Faktor Yang Mempengaruhi Perkembangan Moral Pada Anak Usia Dini. Al-Athfaal: Jurnal Ilmiah Pendidikan Anak Usia Dini, 3(1), 1-15. https://doi.org/10.24042/ajipaud.v3i1.6500

Gintings, V. (2020). Angka Kekerasan Terhadap Anak Tinggi Di Masa Pandemi, Kemen Pppa Sosialisasikan Protokol Perlindungan Anak.

Habibie, A. (2017). Pengenalan Aurat Bagi Anak Usia Dini Dalam Pandangan Islam. Early Childhood: Jurnal Pendidikan, 1(2), 76-85. https://doi.org/10.35568/earlychildhood.v1i2.115

Hidayah, N., \& Palila, S. (2018). Kesiapan Menghadapi Menarche Pada Remaja Putri Prapubertas Ditinjau Dari Kelekatan Aman Anak Dan Ibu. Psympathic: Jurnal Ilmiah Psikologi, 5(1), 107-114. https://doi.org/10.15575/psy.v5i1.2021

Ige, O. K., \& Fawole, O. I. (2011). Preventing Child Sexual Abuse: Parents' Perceptions And Practices In Urban Nigeria. Journal of Child Sexual Abuse, 20(6), 695-707. https://doi.org/10.1080/10538712.2011.627584

Jatmikowati, E. T., Angin, R., \& Ernawati. (2015). Model Dan Materi Pendidikan Seks Anak Usia Dini Perspektif Gender Untuk Menghindarkan Sexual Abuse. Cakrawala Pendidikan, No. 03, 434-448.

Kementerian Pemberdayaan Perempuan dan Perlindungan Anak. (2020). Profil Anak Indonesia 2020. Kementrian Pemberdayaan Perempuan dan Perlindungan Anak.

Kustanto, L. (2015). Analisis Naratif : Kemiskinan Dalam Program Reality Tv. Jurnal Rekam, 11(2), 109-124.

Mardina, R. (2019). Infodatin Kekerasan Terhadap Anak Dan Remaja (p. ISSN 2442-7659). Kementerian Kesehatan Republik Indonesia.

Mashudin, I. (2016). Sanksi Tindak Pidana Pelecehan Seksual Terhadap Anak Dalam Perspektif Hukum Pidana Islam. Universitas Islam Negeri Walisongo.

Miller, R. R. (2018). Talking To Your Child About Periods. The Nemours Foundation.

Mukti, A. (2016). Pendidikan Seks Untuk Anak Usia Dini Perspektif Islam. Harkat: Media Komunikasi Islam Tentang Gender Dan Anak, 12(2), 89-98.

Octaviana, S. N. (2019). Child Sexual Abuse In Indonesia: History And Challenge In Legal Perspective. IJCLS (Indonesian Journal of Criminal Law Studies), 4(1), 83-92. https://doi.org/10.15294/ijcls.v4i1.19613

Oktarina, A., \& Suryadilaga, M. A. (2020). Pendidikan Seks Usia Dini Dalam Kajian Hadis. Riwayah: Jurnal Studi Hadis, 6(2), 363-386.

Sinanan, A. N. (2011). The Impact Of Child, Family, And Child Protective Services Factors On Reports Of Child Sexual Abuse Recurrence. Journal of Child Sexual Abuse, 20(6), 657-676. https://doi.org/10.1080/10538712.2011.622354

Sunanih. (2017). Kemampuan Membaca Huruf Abjad Bagi Anak Usia Dini Bagian Dari 
Perkembangan Bahasa. Early Childhood: Jurnal Pendidikan, 1(1), 1-12.

UNESCO Office Jakarta. (2013). Buku Suplemen Bimbingan Teknis Kesehatan Reproduksi: Pelecehan Seksual. BKKBN \& UNESCO.

Wiludjeng, J. M. H. (2016). Kekerasan Seksualdan Uu Perlindungan Anak Dalam Pandangan Orangtua Siswa Dan Guru Sd 09 Bendungan Hilir Jakarta. Jurnal Paradigma Hukum Pembangunan, 1(3), 198-213.

Zhang, W., Ren, P., Yin, G., Li, H., \& Jin, Y. (2020). Sexual Abuse Prevention Education For Preschool-Aged Children: Parents' Attitudes, Knowledge And Practices In Beijing, China. Journal of Child Sexual Abuse, 29(3), 295-311. https://doi.org/10.1080/10538712.2019.1709240 